\title{
Morphological aspects and anatomy of the fruit, seeds and seedlings of Pentaclethra macroloba (willd.) Kuntze (Fabaceae) ${ }^{1}$
}

\author{
Rubiene Neto Soares ${ }^{2 *}$ (D), Ronaldo Oliveira dos Santos² (iD, \\ Breno Marques da Silva e Silva² ${ }^{2}$
}

\begin{abstract}
The aim of this study was to describe the morphology of fruit, seeds and seedlings, as well as the anatomy of the seed and the seedling of Pentaclethra macroloba (Willd.) Kuntze. Morpho-biometry was performed on fifty fruit samples and one hundred seeds. To describe the sequences of the morphological events of the germination stages, ten seeds were placed to germinate. Anatomical analysis was performed in a scanning electron microscope with seed samples and seedling leaves. The species has leguminous type fruit of 16.1 to $45.2 \mathrm{~cm}$ length and 4.1 to $7.3 \mathrm{~cm}$ width; seeds have a pleurogram and are eurispermic, ovoid, deltoid to elliptical and measure from 3.8 to $6.1 \mathrm{~cm}$ length and 2.5 to $5.7 \mathrm{~cm}$ width. Anatomically, the cotyledons are composed of thin-walled parenchyma cells with various oil cells. The seedlings have bipinnate leaves, with waxes and simple trichomes at the margins of the adaxial surface and paracytic stomata on the abaxial surface. The epicotyl is slightly twisted, with caducous cataphylls and a first pair of alternate eophylls. Germination is of the phanero-hypogean-reserve type. Taxonomic recognition of this species is possible in the field through the external morphological traits and can help in identification of saplings.
\end{abstract}

Index terms: Amazon, leguminous plant, pracaxi, floodplain forest.

\section{Aspectos morfológicos e anatomia de frutos, sementes e plântulas de Pentaclethra macroloba (willd.) kuntze (Fabaceae)}

\begin{abstract}
RESUMO - O estudo objetivou descrever a morfologia de fruto, semente e plântula, bem como a anatomia da semente e plântula de Pentaclethra macroloba (Willd.) Kuntze. A morfo-biometria foi realizada em cinquenta frutos e cem sementes. Para descrição das sequências dos eventos morfológicos dos estágios de germinação, dez sementes foram colocadas para germinar. A análise anatômica foi realizada em microscópio eletrônico de varredura com amostras de sementes e folhas de plântulas. A espécie apresenta fruto do tipo legume, medindo 16,1 a 45,2 cm de comprimento, e 4,1 a 7,3 cm de largura; semente com pleurograma, eurispérmica, ovoide, deltoide a elíptica, possuindo dimensões entre 3,8 a $6,1 \mathrm{~cm}$ de comprimento e 2,5 a 5,7 cm de largura. Anatomicamente, os cotilédones são compostos de células parenquimáticas de paredes delgadas e com diversas células oleíferas. As plântulas possuem folhas bipinadas, com ceras e tricomas simples nas margens da face adaxial e estômatos paracíticos na face abaxial. O epicótilo é levemente tortuoso; com catáfilos caducos e primeiro par de eófilos alternos. A germinação é do tipo fânero-hipógea-armazenadora. O reconhecimento taxonômico da referida espécie é possível no campo por meio dos caracteres morfológicos externos, podendo auxiliar na identificação de plantas jovens.
\end{abstract}

Termos para indexação: Amazônia, leguminosa, pracaxi, floresta de várzea.

\section{Introduction}

Popularly known in the Amazon region as pracaxi, Pentaclethra macroloba (Willd.) Kuntze belonging to the Fabaceae family, Mimosoideae subfamily, is a characteristic specie of the river banks of the floodplain forests of the Amazon (APG III, 2009). With a height of approximately $14 \mathrm{~m}$, it has a dense canopy and straight to twisted trunk. It is verrucose in green and gray tones, with elliptical lenticels and its base is formed of small buttresses (Lorenzi, 2009; Dantas et al. 2017).

${ }^{1}$ Submitted on 4/15/2019. Accepted for publication on 9/1/2019.

${ }^{2}$ Universidade do Estado do Amapá, 68906-970 - Macapá, AP, Brasil.

*Corresponding author <rubienesoares.ueap@gmail.com> 
Pracaxi seeds are of economic importance in the NonWood Forest Products (NWFP) sector, especially in the phytotherapeutic and cosmetics industry that uses the oil coming from its seeds as raw material in products that are applied to treat muscle pain, inflammation and snakebite, and as an alternative treatment in patients with diabetic ulcers (Simmons et al., 2015); the bark is also used as a treatment for diarrhea (Crespi and Guerra, 2013). The study of Santiago et al. (2005) found potential in pracaxi oil; the authors confirmed the larvicidal effectiveness of a chemical component present in the oil against larvae of the Aedes aegypti mosquito, a vector of diseases such as dengue fever, yellow fever, the chikungunya virus and the zika virus.

In Brazil, there are numerous studies on the morphology and anatomy of fruit, seeds and seedlings of forest species; however, they are still restricted to few species, especially when dealing with trees, like pracaxi, in areas subject to flooding (Moreira and Moreira, 1996). Given this problem and considering the biodiversity that exists in floodplain forests, it is necessary to broaden the dendrological information on the species in this ecosystem since this information can assist new studies in the sphere of forest management, conservation and ecology.

Knowledge of fruit, seed and seedling morphology contributes to better understanding of the biology of the species and provides important support for studies on regeneration through seeds under natural conditions (Araújo-Neto et al., 2002; Barroso et al., 2012; Reis et al., 2016). Given this situation, efforts in getting to know forest composition run up against the difficulty of finding consistent morphological studies that can assist in classification of species, especially those belonging to the Fabaceae family, since it is subdivided into botanical subfamilies that encompass a wide variety of species with sometimes quite similar characteristics, thus requiring more thorough and well-reasoned morphological descriptions for correct classification of the species in the taxonomic and phylogenetic sphere.

Incorrect identification of flora by "woodsmen" without following technical and scientific criteria generates irreparable damage, both for maintaining the species in the natural environment and for commercialization of its natural resources or Wood Forest Products (WFPs) (Procópio and Secco, 2008). Thus, studies on the morphological and anatomical aspects of the fruit, seeds and seedlings of tropical forests constitute a useful tool in species identification, serving as a basis for other studies in the branches of forest sciences, as mentioned by Sánchez-Coronado et al. (2007) and Ribeiro et al. (2015). In this context, some studies have already been developed with forest species of the Fabaceae family regarding morphoanatomy of the fruit, seed and seedling (Sousa et al., 2010;
Hartmann and Rodrigues, 2014; Ribeiro et al., 2015).

Considering that the external and internal traits of fruit, seeds and seedlings constitute quite a sure criterion in taxonomic, phylogenetic and ecophysiological studies, the aim of this study was to describe the morphology of the fruit, seed and seedling, as well as the anatomy of the seed and seedling of Pentaclethra macroloba (Willd.) Kuntze.

\section{Material and Methods}

The mother trees selected are in a floodplain forest area in the Distrito da Ilha de Santana $\left(00^{\circ} 04^{\prime} 00^{\prime \prime} \mathrm{S}\right.$ and $51^{\circ} 08^{\prime} 00^{\prime \prime}$ W) in the municipality of Santana, Amapá, Brazil. This municipality is drained by the Amazon River drainage basin and the Matapi River. Its climate, according to the Köppen classification, is type Amw, consisting of a rainy season from November to June and a dry season from July to October, where the mean temperature is never lower than $18^{\circ} \mathrm{C}$ and annual oscillation is generally less than $5{ }^{\circ} \mathrm{C}$, with a rainfall regime in the amount of around 1300 to $1900 \mathrm{~mm}$, with a well-defined dry period (ZEE, 2008).

Fruit was harvested directly from fifteen trees from January to April 2016, when the fruit was already falling spontaneously, i.e., in the period of complete physiological maturity, with the assistance of a pruning shears $(5 \mathrm{~m})$. Fifty whole pieces of fruit that were ripe or in the final stage of maturity and not deformed were separated at random. The external characteristics observed were in regard to type, shape, color, indumenta, texture, dehiscence, consistency, shine and number of seeds per fruit.

In a lot of one hundred seeds, biometry was evaluated, measuring the variables of length, width and thickness, with the assistance of a digital caliper and a millimeter ruler. Fresh matter was determined in a $0.001 \mathrm{~g}$ precision balance. The external morphological characteristics (color, texture and consistency of the seed coats, shape and edges, hilum and micropyle position, raphe) and internal morphological characteristics (embryo, cotyledons, hypocotyl-radicle axis, plumule and presence of the endosperm) were observed and described.

To describe the sequences of the morphological events of the germination process, ten seeds were placed to germinate in plastic trays $(32 \mathrm{~cm} \times 25 \mathrm{~cm} \times 2.5 \mathrm{~cm}$ ) between washed and sterilized sand, moistened with $0.1 \%$ Benlate $^{\circledR}$ aqueous solution at $60 \%$ of retaining capacity (Brasil, 2009), kept at ambient temperature and $25 \%$ shade. Morphological events of the stages of germination were registered (Nikon DSLR D3200 digital camera) and documented three times every week, observing primary root development, the emergence of secondary roots and expansion of the epicotyl and of the first pair of true leafs 
(Silva et al., 2015). For treatment and vectorization of the images generated, the GIMP 2.8.18 (GNU Image Manipulation Program) and CorelDraw ${ }^{\circledR}$ X7 software were used.

For anatomical observation, the seeds were immediately fixed in $\mathrm{FAA}_{70}$ (formaldehyde, acetic acid and 70\% ethanol) for seven days in order to block cell metabolism. After this process, they were conserved in $70 \%$ ethanol. The seedling samples were fixed in $\mathrm{FAA}_{50}$ at various phases after germination, according to Loureiro et al. (2013). Images of seeds and seedlings were made in a scanning electron microscope (TM 3030 Plus Tabletop Microscope, Hitachi). The terminology used for the morpho-anatomical descriptions were based on studies of Garwood (1996), Damião-Filho and Môro (2005) and Barroso et al. (2012).

\section{Results and Discussion}

The fruit of Pentaclethra macroloba (Willd.) Kuntze is a legume, dry, dehiscent, woody, polyspermic, long, dorsoventrally flattened, with an ondulate margin and pseudoseptum, lateral placentation, prominent seminal nucleus, acute to obtuse apex and acute base, persistent peduncle and a suture line from the peduncle to the apex measuring from 16.1 to $45.2 \mathrm{~cm}$ length, 4.1 to $7.3 \mathrm{~cm}$ width, 1.2 to $1.5 \mathrm{~cm}$ thickness and with three to six seeds per fruit (Figures 1A-B).

The presence of the dorsal and ventral suture line is related to the dehiscence mechanism, since the pracaxi fruit, upon reaching maturity, opens in the longitudinal direction by means of separation of two valves that keep them joined at the base, releasing the seeds to a distance far from the mother plant (Figure 1E).
The exocarp of pracaxi is glabrous, slightly wrinkled longitudinally, fiber-chartaceous and from light green to brown, over different stages of maturity (Figures 1A-B). The mesocarp is fibrous and of light green to brown color over different stages of maturity. The endocarp is glabrous, of woody fiber, smooth and from light green to brown over different stages of maturity (Figure 1F).

The pracaxi seeds are eurispermic, exalbuminous, glabrous, slightly wrinkled, shiny, from ovoid and deltoid to elliptical, with a rounded apex and obtuse to acute base, measuring from around 3.0 to $6.1 \mathrm{~cm}$ length, 2.5 to $5.7 \mathrm{~cm}$ width, 0.9 to 1.4 $\mathrm{cm}$ thickness and 4.7 to $20.8 \mathrm{~g}$ of fresh matter (Figure 2A). Williamson and Costa (2000) found approximately $6.9 \mathrm{~g}$ of fresh matter for the seeds of Pentaclethra macroloba, a value lower than that found in this study.

The seed has a thin type seed coat, bitegmic, glabrous, slightly wrinkled, slightly shiny and from light green to brown color over different stages of maturity, with a pleurogram in the shape of an "inverted U”, open apices, with elliptical hilum (obliterate) and circular micropyle; however, both are homochromous, apical and small in regard to size (Figure 2C). According to Gunn (1981), the pleurograms, from the perspective of ontogeny, can show differences among genera, tribes and subfamilies. Furthermore, this author cites that in Mimosoideae seeds these pleurograms are the result of a break in the exotestal palisade layer.

Araújo-Neto et al. (2002) report that in the Faboideae subfamily the pleurogram is not present; however, this structure is present in around $67 \%$ to $70 \%$ of the Mimosoideae genera and in $9 \%$ to $14 \%$ of Caesalpinioideae. This characteristic was observed in the same subfamily as pracaxi for other species of

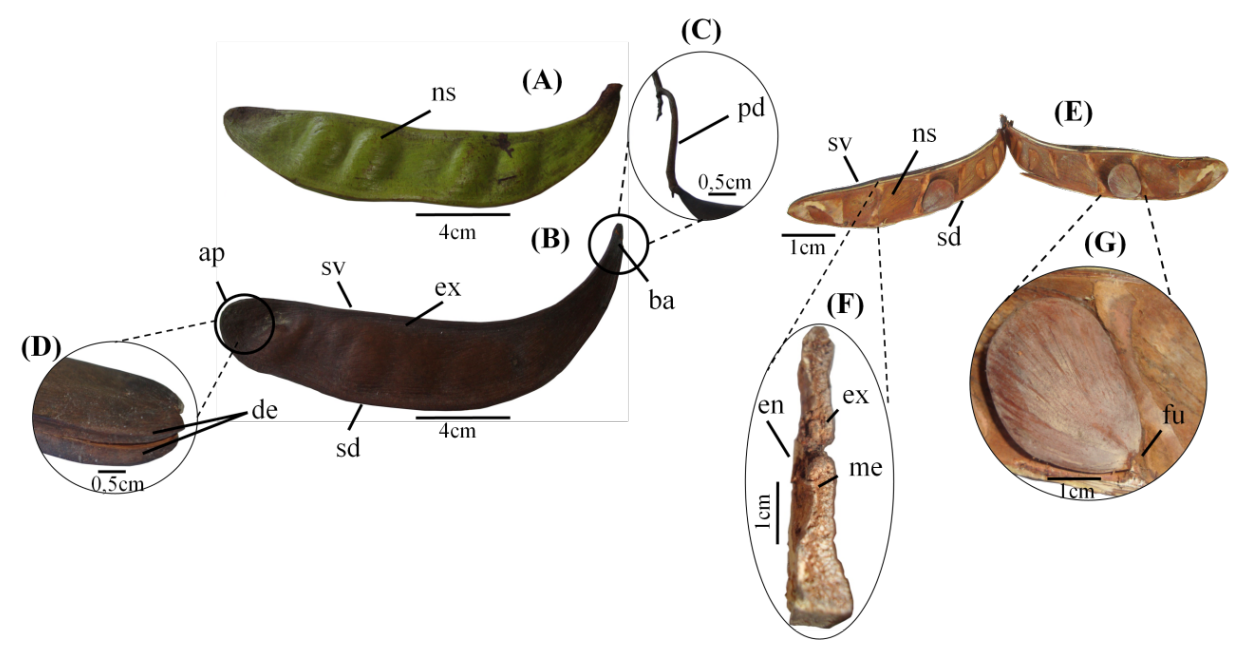

Figure 1. Morphological aspects of the fruit of Pentaclethra macroloba. A-unripe fruit; $\mathrm{B}$ - ripe fruit; $\mathrm{C}$ - detail of the peduncle (pd); D - moment of dehiscence (de); E - open fruit (slightly curled valves); F - inner structure of the valve; $\mathrm{G}-$ seed attached to the fruit. Abbreviations: ex = exocarp, en = endocarp, me = mesocarp, ap $=$ apex, ba $=$ base, $n s=$ seminal nucleus, $\mathrm{sd}=$ dorsal suture, $\mathrm{sv}=$ ventral suture and $\mathrm{fu}=$ funiculus. 
Mimosoideae, such as Albizia edwallii (Hoehne) Barneby \& J. W. Grimes (Duarte et al., 2015) and Acacia polyphylla DC. (Araújo-Neto et al., 2002).

The embryo is elliptic-basal, invaginated, straight, with an embryonic axis differentiated into epicotyl and hypocotylradicle that is short, straight, cylindrical and from white to cream color, with fleshy cotyledons, concave-convex, forming a hollow inner portion, from white to cream color, with slightly prominent seminal veins (Figures $2 \mathrm{E}-\mathrm{G}$ ). Anatomically, the cotyledon is composed of parenchyma cells with thin walls and with diverse oil cells (Figure 3).

The pracaxi seed coat has well-differentiated exotesta, mesotesta and endotesta covered by a cuticle. The exotesta is formed by a single layer of polygonal cells. In the transversal
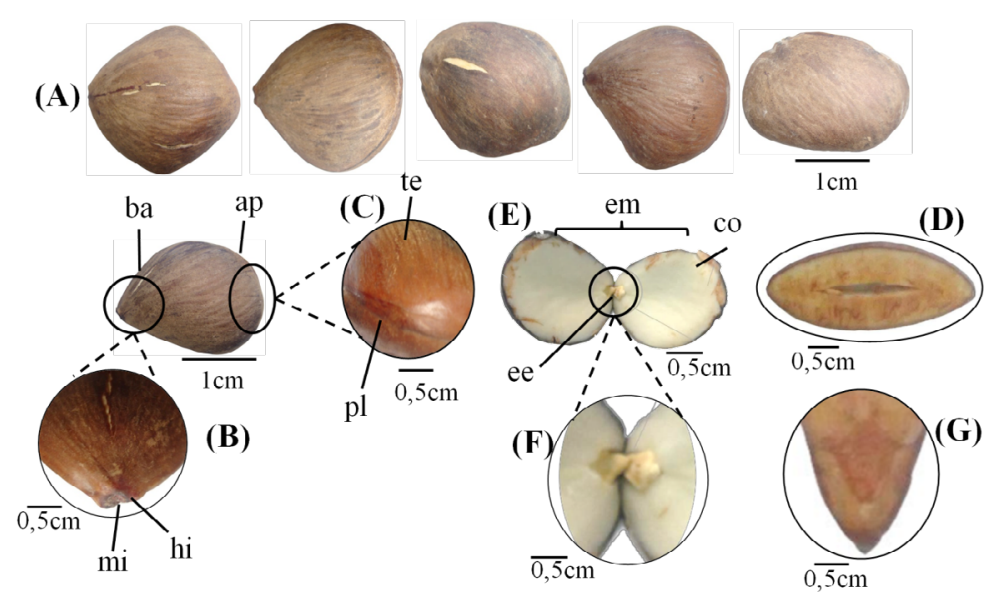

Figure 2. Morphological traits of the seeds of Pentaclethra macroloba. A - external morphological variations; B - hilum (hi) obliterated with the remains of funiculus and micropyle (mi); C - seed coat (te) and pleurogram (pl); D - longitudinal section of the seeds; $\mathrm{E}$ - hollow inner portion; $\mathrm{F}$ - embryo; $\mathrm{G}$ - longitudinal section of the embryo. Abbreviations: ap = apex, $\mathrm{ba}=$ base, $\mathrm{ee}=$ embryonic axis, $\mathrm{co}=$ cotyledon and $\mathrm{em}=$ embryo.
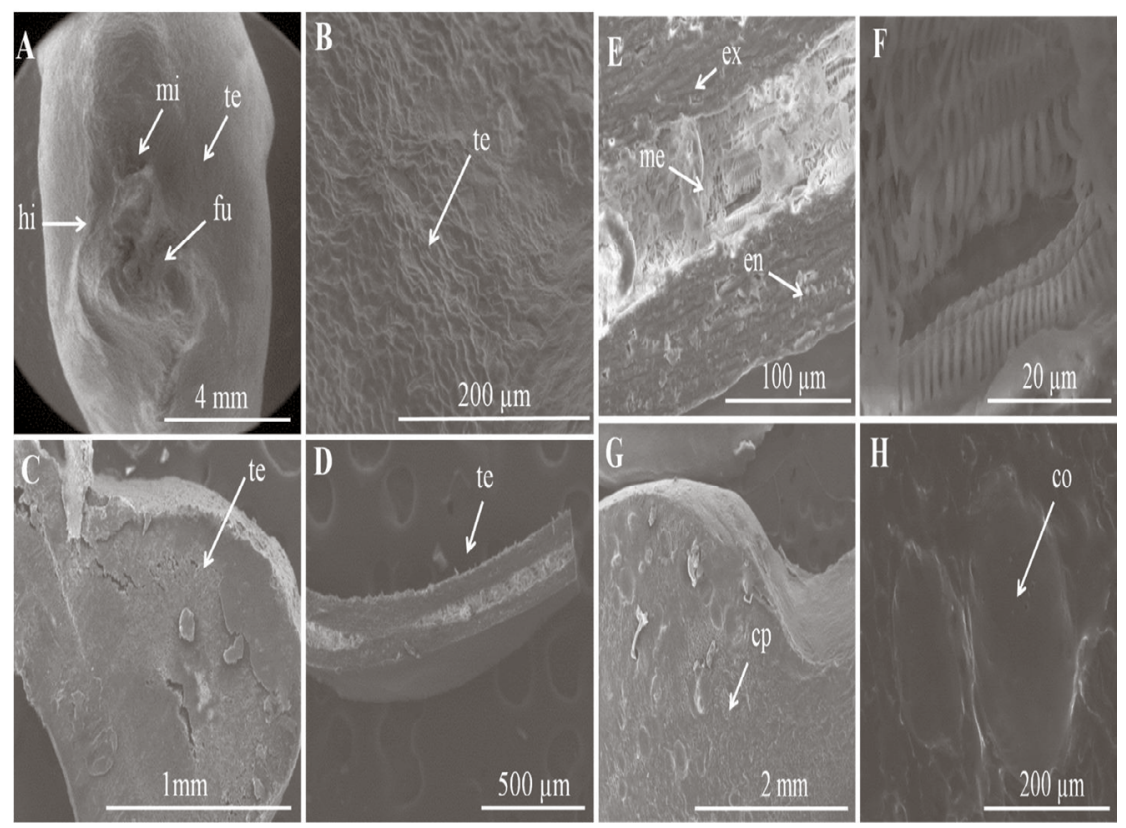

Figure 3. Anatomical image of Pentaclethra macroloba seed obtained through scanning electron microscopy. A- external hilar (hi) view of the seed; B - external view of the seed coat (te); $\mathrm{C}$ - transversal section of the seed coat (hilar region); $\mathrm{D}, \mathrm{E}, \mathrm{F}$ - transversal section of the seed coat (central region); $\mathrm{G}$ - parenchymatous cells (cp) of the cotyledon; $\mathrm{H}$ parenchymatous cells of the cotyledon (oil cell - co). Abbreviations: $\mathrm{fu}=$ funiculus, $\mathrm{mi}=$ micropyle, $\mathrm{ex}=\mathrm{exotesta,}$ $\mathrm{me}=$ mesotesta and $\mathrm{en}=$ endotesta. 
view, the cells have the shape of a cube, while the primary wall is thickened. There is invagination to the center of the cells, forming a central cavity without thickening of the wall. The degree of thickening in each cell diminishes for the mesotesta, since it is constituted of various layers of parenchymatous cells and with anficrival vascular bundles and the endotesta consists of a layer of cells with thick walls (Figure 3E).

The hollow inner portion of the pracaxi seeds is responsible for reduction in its density below the basic density of water and, consequently, this allows dispersion through hydrochory in the floodplains in the Amazon. According to Parolin, Wittmann and Ferreira (2013), forest species produce fruit and/or seeds that may have pre-adaptations, such as wings or hairs, which in other ecosystems increase dispersion through wind, but, at the same time, increase floating in water and an adaptation is the formation of floating tissues with large spaces full of air. Williamson and Costa (2000) observed that floating of pracaxi seeds is related to specific gravity and not to size and depends on imbibition.

Seven days after sowing, pracaxi germination began with rupture of the seed coat at the base of the seed near the hilum and the micropyle, with emergence of a primary root in a cylindrical shape of a yellow to cream color, without apparent absorbent hairs (Figure 4A). This emergence of the primary root is also characteristic of other species within the Fabaceae family, for example, Ormosia paraensis Ducke (Silva et al., 2015).

The hypocotyl of pracaxi seedlings is cylindrical, smooth, glabrous, from white to cream color and with little development, since emergence of the primary root is near the cotyledons. Lengthening of the hypocotyl was not observed during the process of seedling development (Figure 4A). In diverse species of Fabaceae with hypogeal seed germination, there is little to no growth of the hypocotyl in seedlings (Gurgel et al., 2012; Silva et al., 2015).

At fourteen days after sowing, the naked eye could discern formation of the secondary root that was slightly curved, cylindrical, smooth, glabrous and cream colored, reaching from 3.0 to $4.3 \mathrm{~cm}$ length (Figure 4B). These characteristics were described by Silva et al. (2015) for the root of Ormosia paraensis Ducke seedlings, though with a smaller number of secondary roots. The secondary roots emerged with approximately 1.0 to $1.7 \mathrm{~cm}$ length, and at twenty one days the cotyledons were released from the seed coat (Figure 4C). After that, there was growth of the epicotyl, with lenticels, of a red to slightly purple-violet color, discretely shiny, smooth and glabrous, with triangular cataphylls, acute, sessile, alternating and small. However, before formation of the eophyll, the last cataphylls were similar to the first, though larger and opposing (Figures 4C-E).

The occurrence of lenticels on the stems is characteristic of seedlings from floodplain forests, because they assist in resistance to anoxia and hypoxia related to rainfall and tide regimes (Parolin, 2009). In the plumule, there is formation of the stipulated eophyll (intrapetiolate filiform stipules), of red to slightly purple-violet color, slightly shiny, smooth and glabrous to the naked eye (Figures 4C-E). The epicotyl of the seedlings measured approximately 14 to $15 \mathrm{~cm}$ length, which was slightly twisted, cylindrical, elongated, glabrous and of dark green to brown color, with caduceus cataphylls and the first pair of eophylls alternating (Figure 4D).

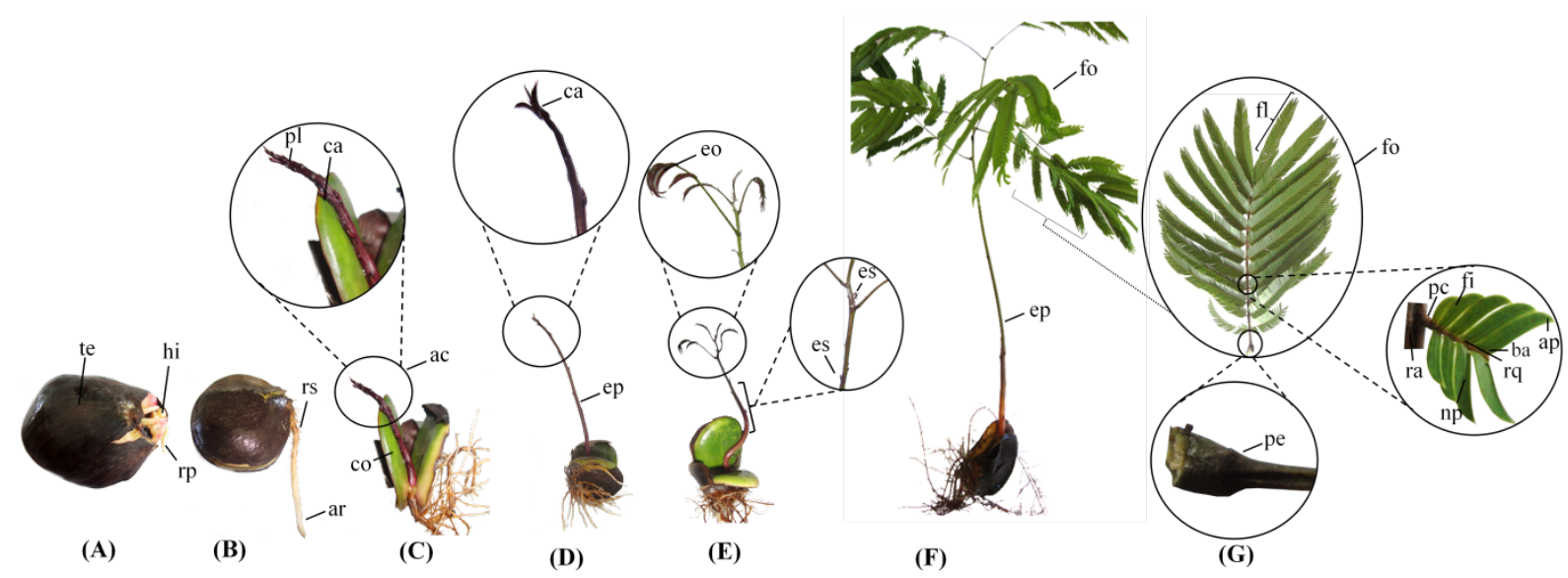

Figure 4. Stages of seedling development of Pentaclethra macroloba. A - primary root emergence (rp); B - emergence and elongation of the secondary root (rs); C - release of the cotyledons (co) of the seed coat (te); D - last pair of cataphylls (ca) and formation of the plumule (pl); E - first pair of eophyll (eo); F - seedling; $\mathrm{G}$ - leaf detail. Abbreviations: hi = hypocotyl, ar = root apex, ac = stem apex, co = cotyledon, ep = epicotyl, es = stipule, fo = leaf, pe = petiole (pulvinus), $\mathrm{fl}=$ leaflet, $\mathrm{fi}=$ small leaflet, $\mathrm{pc}=$ petiolule, $\mathrm{ra}=$ rachis, $\mathrm{np}=$ main vein, $\mathrm{rq}=$ rachilla, $\mathrm{ba}=\mathrm{base}$ and $\mathrm{ap}=\mathrm{apex}$. 
Formation of the pracaxi seedlings occurred at twenty eight days after sowing, at which time the root and stem system was completely developed (Figure 4F). The seedling root is pivoting, axial, cylindrical, without absorbent hairs apparent to the naked eye, but with nodules, confirming the results obtained by Souza et al. (1994), who reported that pracaxi has considerable potential for nitrogen fixation through this nodulation.

Leaves are composed in a bipinnate manner, with long petioles, thickened pulvini and with a cylindrical, smooth, glabrous and green to dark green rachis, measuring approximately 12 to $30 \mathrm{~cm}$ length (Figure 4F). The leaflets are opposing and have long petiolules formed by opposing leaflets, elliptical, with sessile petiolules of the entire edge, with single and hyaline trichomes, hypostomatic, with an acute and asymmetric base and apex from acute to apiculate and slightly asymmetric. They are two-colored, i.e., dark green, shiny and with wax on the adaxial surface and light green and lightly opaque on the abaxial surface (Figures $4 \mathrm{G}$ and 5). The leaves are classified as hypostomatic, i.e., that have stomata arranged only abaxially, a characteristic that is also observed in other leguminous plants, as for example, in Schizolobium parahyba (Vell.) Blake, Copaifera langsdorffii Desf. and Hymenaea stilbocarpa Hayne (Moreira-Coneglian and Oliveira, 2006).

The adaxial surface of the leaflets have irregular cells, juxtaposed and covered with wax, with simple and hyaline trichomes on all the edges. However, the main vein (tertiary vein) is slightly salient from the leaflets; the cells are more regular and elongated. In the abaxial region, the cells are equally irregular and juxtaposed; however, with paracytic stomata and, once more, on the main vein salient from the leaflets, the cells are regular and longitudinally elongated (Figure 5).

Throughout the germination and seedling development phase, the cotyledons remained present up to complete formation of the plant, becoming opaque, pale green, slightly hanging, beginning the process of generalized and uniform chlorosis, remaining totally clear yellow until reaching a straw-colored tone, entering into senescence. Germination of pracaxi seeds is of the PHR (phanero-hypogeal-reserve) type, i.e., during the germination process, the cotyledons remained above the substrate and completely surrounded by the seed coat; the radicle-hypocotyl axis is unipolar (Figure 4).

PHR germination was also described in studies carried out
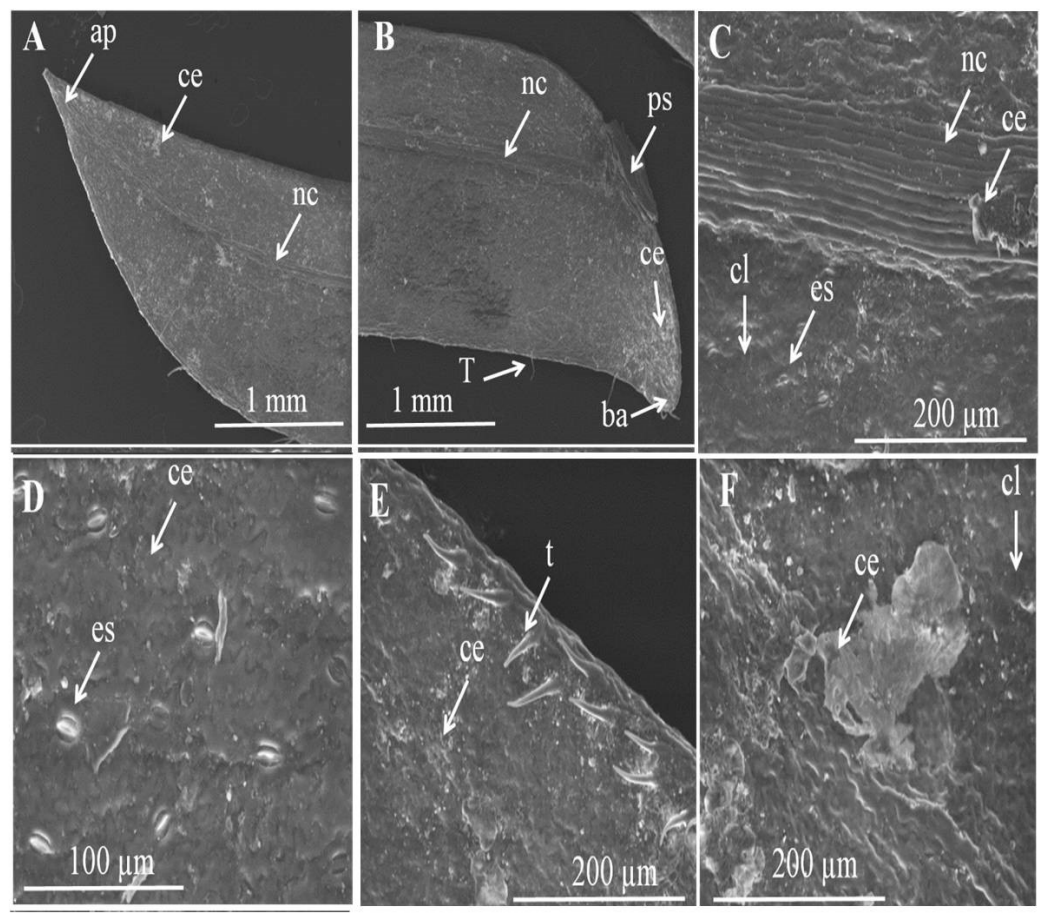

Figure 5. Image of the leaflets of leaves of Pentaclethra macroloba obtained through scanning electron microscopy. A - apex of the adaxial surface; $\mathrm{B}$ - base of the adaxial surface; $\mathrm{C}$ - central vein, irregular cells and stomata in the abaxial epidermis; D - paracytic stomata in the abaxial epidermis; $\mathrm{E}$ - trichomes in the adaxial epidermis; $\mathrm{F}$ - wax in the adaxial epidermis. Abbreviations: $\mathrm{ce}=$ wax, $\mathrm{ci} / \mathrm{cI}=$ irregular cells, $\mathrm{ps}=$ petiolules, $\mathrm{ap}=\mathrm{apex}, \mathrm{ba}=\mathrm{base}, \mathrm{nc}=$ main vein (tertiary vein), es $=$ stomata and $\mathrm{t} / \mathrm{T}=$ trichomes. 
in seedlings of forest species of the subfamily Mimosoideae, such as Inga edulis Mart. (Gurgel et al., 2012). Feitoza et al. (2014) used the type of germination to differentiate three species of the genus Macrolobium originating from flooded environments - Macrolobium acaciifolium (Benth.) Benth. had CHR (crypto-hypogeal-reserve) type germination and the species Macrolobium bifolium (Aubl.) Pers. and Macrolobium pendulum Willd. ex Vogel had PER (phanero-epigeal-reserve) type germination. In general, in the Amazon, the native leguminous plants that predominate in environments prone to flooding mostly exhibit 59\% hypogeal germination, according to studies of Moreira and Moreira (1996). Corroborating this affirmation, the study published by Parolin, Ferreira and Junk (2003) showed that hypogeal germination has proven to be more efficient for species of flooded environments and this increases their frequency.

The floodplain forests are very particular environments because, due to the rainfall and tide regimes, they have periodic conditions of a lack of or a reduction in oxygen (anoxia/hypoxia) in the soil. Excessive water in the vegetation becomes a limiting factor for establishment of certain species and there are those that have found adaptive mechanisms for survival in this medium (Wittmann et al., 2010). Thus, taking the morpho-anatomical results obtained in the present study as a basis, it can be inferred that the size of the seed, as well as its amount of reserves and inner structure allow good conditions of viability to be maintained during flooding in the vegetation, showing rapid germination during the period of seasonality. This probably reflects the adaptive ecophysiological process that it performs in this forest type and germination may also occur over the water layer during the flows of flooding, as shown in other studies (Parolin, 2009; Parolin et al., 2010).

This same understanding regarding adaptation applies to the structures of other organs, as for example, the arrangement of the stomata in the limbus, as observed in the abaxial region of the leaves of Pentaclethra macroloba, i.e., of the hypostomatic type, which grants it greater ability to regulate the evapotranspiration process, keeping in mind the adverse conditions to which it is subjected. Therefore, the presence of stomatal cells only in the lower part of the leaf blade can assist in differentiation from the other species within the Mimosoideae subfamily and can also be the point of departure for other studies regarding its nature, permeability and chemical composition.

However, little is known regarding the histological or physiological studies that assist in understanding the morphological response of the species in tropical forests, especially in the Amazon floodplains, thus making additional studies necessary to fill these gaps. It should be emphasized that this premise applies to the species in question because, in Figure 3F, it was not possible to describe which, anatomically, are the cells that exist in the innermost region of the seed coat, the reason for which new studies are suggested.

\section{Conclusions}

According to descriptive analyses, it was possible to characterize and illustrate the morphology and anatomy of the species studied through the fruit, seed, or seedling, obtaining information that assists in taxonomic recognition, as well as in its identification in the field when natural regeneration is to be evaluated. Thus, the illustrations will also serve to subsidize future studies that aim at a comparative analysis between morpho-anatomical traits that are common to other species of the Mimosoideae subfamily. In general, the morphological adaptations observed in Pentaclethra macroloba exemplified only some of the strategies for its growth and survival in the Amazon floodplain forests.

\section{References}

APG III. The angiosperm phylogeny group. An update of the angiosperm phylogeny group classification for the orders and families of flowering plants. Botanical Journal of the Linnean Society, v.161, n.2, p.105-121, 2009. https://academic.oup.com/ botlinnean/article/161/2/105/2418337

ARAÚJO-NETO, J.C.; AGUIAR, I.B.; FERREIRA, V.M.; PAULA, R.C. Caracterização morfológica de frutos e sementes e desenvolvimento pós-seminal de monjoleiro (Acacia polyphylla DC.). Revista Brasileira de Sementes, v.24, n.1, p.203-211, 2002. http://www.scielo.br/scielo. php?pid=S0101-31222002000100029\&script=sci_abstract\&tlng=pt

BARROSO, G.M.; MORIN, M.P.; PEIXOTO, A.L.; ICHASO, C.L.F. Frutos e sementes: morfologia aplicada à sistemática de dicotiledôneas. Viçosa: Editora UFV, 2012. 443p.

BRASIL. Ministério da Agricultura, Pecuária e Abastecimento. Regras para análise de sementes. Ministério da Agricultura, Pecuária e Abastecimento. Secretaria de Defesa Agropecuária. Brasília: MAPA/ACS, 2009. 395p. http://www.agricultura.gov.br/assuntos/ insumos-agropecuarios/arquivos-publicacoes-insumos/2946 regras_analise_sementes.pdf

CRESPI, B.; GUERRA, G.A.D. Ocorrência, coleta, processamento primário e usos do pracaxi (Pentaclethra macroloba (Willd.) Kuntze) na Ilha de Cotijuba, Belém, PA. Revista Brasileira de Agroecologia, v.8, n.3, p.176-189, 2013. http://revistas.aba-agroecologia.org.br/ index.php/rbagroecologia/article/view/13297/0

DANTAS,A.R.; MARANGON,L.C.; GUEDES, M.C.; FELICIANO, A.L.P; GUEDES, A.C.L. Spatial distribution of a population of Pentaclethra macroloba (willd.) Kuntze in a floodplain forest of the Amazon estuary. Revista Árvore, v.41, n.4, p.1-11, 2017. http://www. scielo.br/pdf/rarv/v41n4/0100-6762-rarv-41-04-e410406.pdf 
DAMIÃO-FILHO, C.F.; MÔRO, F.V. Morfologia Vegetal. 2 ed. Jaboticabal: FUNEP, 2005. 172p.

DUARTE, M.M.; FREITAS, J.E.M.; BLUM, C. T.; NOGUEIRA, A.C. Germinação e morfologia de sementes e plântulas de Albizia edwallii (Hoehne) Barneby and JW Grimes. Revista Caatinga, v.28, n.3, p.166-173, 2015. http://www.scielo.br/scielo.php?script=sci arttext\&pid=S1983-21252015000300166

FEITOZA, G.V.; SANTOS, J.M.U.; GURGEL, E.S.C.; OLIVEIRA, D.M.T. Morphology of fruits, seeds, seedlings and saplings of three species of Macrolobium schreb. (Leguminosae, Caesalpinioideae) in the Brazilian Amazon floodplain. Acta Botanica Brasilica, v.28, n.3, p.422-433, 2014. http://www.scielo.br/scielo.php?pid=S010233062014000300016\&script $=$ sci_arttext

GARWOOD, N.C. Functional morphology of tropical tree seedlings. In: Swaine, M.D. (ed.). The ecology of tropical forest tree seedlings. Paris: UNESCO, 1996. p.59-129.

GUNN, C.R. Seed topography in the Fabaceae. Seed Science and Technology, v.9, n.3, p.733-737, 1981. http://agris.fao.org/agrissearch/search.do?recordID $=$ XE8280346

GURGEL, E.S.C.; SANTOS, J.U.M.; CARMO BASTOS, M.D.N.; LUCAS, F.C.A. Morfologia de plântulas de Leguminosae e o potencial sistemático. Rodriguésia, v.63, n.1, p.65-73, 2012. http:// rodriguesia-seer.jbrj.gov.br/index.php/rodriguesia/article/view/382

HARTMANN, L.S.; RODRIGUES, R.S. Morfologia de plântulas de Martiodendron excelsum e sua relevância sistemática em Dialiinae (Leguminosae, “Caesalpinioideae”). Rodriguésia, v.65, n.3, p.577586, 2014. https://rodriguesia-seer.jbrj.gov.br/index.php/rodriguesia/ article/view/ID\%20839

LORENZI, H. Arvores brasileiras: manual de identificação e cultivo de plantas arbóreas no Brasil. 3 ed. Nova Odessa: Instituto Plantarum, 2009. 384p.

LOUREIRO, M.B.; TELES, C.A.S.; VIRGENS, I.O.; ARAÚJO, B.R.N.D.; FERNANDEZ, L.G.; CASTRO, R.D.D. Aspectos morfoanatômicos e fisiológicos de sementes e plântulas de Amburana cearensis (fr. all.) a.c. smith (Leguminosae - Papilionoideae). Revista Árvore, v.37, n.4, p.679-689, 2013. http://www.scielo.br/scielo. php?pid=S0100-67622013000400011\&script=sci_abstract\&tlng=pt

MOREIRA, F.M.S.; MOREIRA, F.W. Características da germinação de sementes de 64 espécies de leguminosas florestais nativas da Amazônia, em condições de viveiro. Acta Amazonica, v.26, n.2, p.3-16, 1996. http://www.scielo.br/scielo.php?pid=S0044$59671996000200003 \&$ script $=$ sci_abstract\&tlng=pt

MOREIRA-CONEGLIAN, I.R.; OLIVEIRA, D.M.T. Anatomia comparada dos limbos cotiledonares e eofilares de dez espécies de Caesalpinioideae (Fabaceae). Brazilian Journal of Botany, v.29, n.2, p.193-207, 2006. http://www.scielo.br/scielo.php?pid=S0100$84042006000200001 \&$ script $=$ sci_abstract\&tlng $=$ pt

PAROLIN, P. Submerged in darkness: adaptations to prolonged submergence by woody species of the Amazonian floodplain. Annals of Botany, v.103, n.2, p.359-376, 2009. https://www.ncbi.nlm.nih. gov/pmc/articles/PMC2707320/
PAROLIN, P.; FERREIRA, L.V.; JUNK, W.J. Germination characteristics and establishment of trees from central Amazonian flood plains. Tropical Ecology, v.44, n.2, p.157-169, 2003. http:// www.tropecol.com/pdf/open/PDF_44_2/44203.pdf

PAROLIN, P.; LUCAS, C.; PIEDADE, M.T.F.; WITTMANN, F. Drought responses of flood-tolerant trees in Amazonian floodplains. Annals of Botany, v.105, n.1, p.129-139, 2010. https://academic.oup. com/aob/article/105/1/129/246125

PAROLIN, P.; WITTMANN, F.; FERREIRA, L.V. Fruit and seed dispersal in Amazonian Floodplain tress - a review. Ecotropica, v.19, p.15-32, 2013. https://www.soctropecol.eu/PDF/Ecotropica_2013/ Parolin_et_al_Ecotropica_2013.pdf

PROCÓPIO, L.C.; SECCO, R.S. A importância da identificação botânica nos inventários florestais: o exemplo do "tauri" (Couratari ssp. Cariniana ssp. - Lecythidaceae) em duas áreas manejadas no Estado do Pará. Acta Amazonica, v.38, n.1, p.31-44, 2008. http:// www.scielo.br/pdf/aa/v38n1/v38n1a05

REIS, A.R.S.; FREITAS, A.D.D.; LEÃO, N.V.M.; SANTOSFILHO, G. Morphological aspects of fruits, seeds and seedlings and anatomy of seedlings of Apuleia molaris spruce ex Benth. Journal of Seed Science, v.38, n.2, p.118-128, 2016. http://www.scielo.br/ scielo.php?script=sci_arttext\&pid=S2317-15372016000200118

RIBEIRO, J.W.F.; OLIVEIRA, A.K.M.; RODRIGUES, A.P.D.A.C.; RONDON, E.V. Germination and morphology of seeds and seedlings of Parkia gigantocarpa Fabaceae: Mimosoideae. Revista Floresta, v.45, n.2, p.303-314, 2015. https://revistas.ufpr.br/floresta/article/ view/34504/25608

SÁNCHEZ-CORONADO, M.E.; COATES, R.; CASTRO-COLINA, L.; BUEN, A.G.; PAEZVALENCIA, J.; BARRADAS, V.L.; HUANTE, P.; OROZCO-SEGOVIA, A. Improving seed germination and seedling growth of Omphalea oleifera (Euphorbiaceae) for restoration projects in tropical rain forests. Forest Ecology and Management, v.243, n.1, p.144-155, 2007. https://www. sciencedirect.com/science/article/pii/S0378112707001983

SANTIAGO, G.M.P.; VIANA, F.A.; PESSOA, O.D.L.; SANTOS, R.P.; POULIQUEN, Y.B.M.; ARRIAGA, A.M.C.; BRAZ-FILHO, R. Evaluation of larvicidal activity of triterpenoid saponins isolated of Pentaclethra macroloba (Willd.) Kuntze (Fabaceae) and Cordia piauhiensis Fresen (Boraginaceae) against Aedes aegypti. Revista Brasileira de Farmacognosia, v.15, n.3, p.187-190, 2005. http://www.scielo.br/scielo.php?script=sci_arttext\&pid=S0102$695 \mathrm{X} 2005000300003$

SILVA, B.M.S.; SILVA, C.O.S.; MÔRO, F.V.; VIEIRA, R.D. Morphoanatomy of fruit, seed and seedling of Ormosia paraensis Ducke. Journal of Seed Science, v.37, n.4, p.192-198, 2015. http://www.scielo.br/ scielo.php?script=sci_arttext\&pid=S2317-15372015000400192

SIMMONS, C.V.; BANOV, F.; BANOV, D. Use of a topical anhydrous silicone base containing fatty acids from pracaxi oil in a patient with a diabetic ulcer. SAGE Open Medical Case Reports, v.3, p.205-209, 2015. https://www.ncbi.nlm.nih.gov/pmc/articles/ PMC4857298/ 
SOUSA, D.M.M.; BRUNO, R.D.L.A.; DORNELAS, C.S.M.; ALVES, E.U.; ANDRADE, A.P.D.; NASCIMENTO, L.C.D. Caracterização morfológica de frutos e sementes e desenvolvimento pós-seminal de Tamarindus indica L. - Leguminosae: Caesalpinioideae. Revista Árvore, v.34, n.6, p.1009-1015, 2010. http://www.scielo.br/scielo. php?pid=S0100-67622010000600006\&script=sci_abstract\&tlng=pt

SOUZA, L.A.G; SILVA, M.F.; MOREIRA, F.W. Capacidade de nodulação de cem leguminosas da Amazônia. Acta Amazonica, v.24, n.(1/2), p.9-18, 1994. http://www.scielo.br/scielo.php?pid=S0044$59671994000200009 \&$ script $=$ sci_abstract\&tlng=pt

WILLIAMSON, G.B.; COSTA, F. Dispersal of Amazonian trees: Hydrochory in Pentaclethra macroloba. Biotropica, v.32, n.3, p.548552, 2000. https://www.jstor.org/stable/2663887
WITTMANN, F.; SCHÖNGART, J.; BRITO, J.M.; WITTMANN, A.O.; PIEDADE, M.T.F.; PAROLIN, P.; JUNK, W.J.; GUILLAUMET, J.L. Manual of trees from Central Amazonian varzea floodplains: taxonomy, ecology and use. Manaus: INPA, 2010. 206p.

ZEE. Zoneamento Econômico Ecológico. Macrodiagnóstico do Estado do Amapá: primeira aproximação do ZEE. Macapá: GEA/IEPA, 2008. 140p. http://www.iepa.ap.gov.br/arquivopdf/ macrodiagnostico.pdf. Accessed on June 13 $3^{\text {th }}, 2017$. 